\title{
Randomised controlled trial of colloid infusions in hypotensive preterm infants
}

\author{
E F Emery, A Greenough, H R Gamsu
}

\begin{abstract}
Colloid infusions are often given to treat hypotension in preterm infants. The aim of this work was to assess whether it was the amount of protein or the volume of the colloid infused which accounted for the observed increase in blood pressure. Sixty preterm infants were randomised (20 in each group) to receive $5 \mathrm{ml} / \mathrm{kg} 20 \%$ albumin, $15 \mathrm{ml} / \mathrm{kg}$ fresh frozen plasma, or $15 \mathrm{ml} / \mathrm{kg} \mathrm{4.5 \%}$ albumin. All infusions were given at a rate of $5 \mathrm{ml} / \mathrm{kg} / \mathrm{hour}$ in addition to maintenance fluids. The infants were randomised when hypotensive (systolic blood pressure less than $40 \mathrm{~mm} \mathrm{Hg}$ for two hours). There was no significant difference in the blood pressure of the three groups before or one hour after beginning the infusion. The mean increase in blood pressure one hour after completing the infusion, however, was significantly lower in infants receiving $20 \%$ albumin: $9 \%$ compared with $17 \%$ in the group receiving $4.5 \%$ albumin, and $19 \%$ in the group receiving fresh frozen plasma. It is concluded that the volume infused rather than albumin load is important in producing a sustained increase in blood pressure.
\end{abstract}

\section{(Arch Dis Child 1992,67:1185-8)}

Colloid infusions are often used to treat hypotension in sick preterm infants. This hypotension may result from hypovolaemia due to fluid losses via the kidney and skin and increased leakage from capillaries in the lungs, or from myocardial depression due to asphyxia or hypoxia and resulting poor cardiac output. In the latter instance it seems preferable to avoid a large fluid load, but there are no data available to assess whether the improvement in blood pressure is the result of the protein or of the volume load infused. The aim of this study, therefore, was to compare the effects of colloid infusions of different volumes and protein content on blood pressure levels in hypotensive preterm infants and thus to determine the most efficacious type of colloid infusion.

Department of Child Health, King's College Hospital,

London SE5 9RS

Correspondence to: $\mathrm{Dr}$ Greenough

Accepted 20 June 1992

\section{Subjects and methods}

Consecutive preterm infants were entered the randomised trial when hypotensive not overloaded with fluid. Hypotension was defined as a systolic blood pressure less than $40 \mathrm{~mm} \mathrm{Hg}$ for two successive hours. None of the infants had clinical evidence of fluid over- load. They were randomised by drawing a sealed envelope which instructed that they should receive one of three treatments: 5 $\mathrm{ml} / \mathrm{kg} 20 \%$ albumin $(200 \mathrm{~g} / \mathrm{l}$ albumin - that is, $1 \mathrm{~g} / \mathrm{kg}$ of albumin), or $15 \mathrm{ml} / \mathrm{kg}$ fresh frozen plasma (total protein $80 \mathrm{~g} / \mathrm{l}$, albumin $50 \mathrm{~g} / \mathrm{l}$ that is, $2 \mathrm{~g} / \mathrm{kg}$ of protein or $0.75 \mathrm{~g} / \mathrm{kg}$ of albumin), or $15 \mathrm{ml} / \mathrm{kg} 4.5 \%$ albumin $(45 \mathrm{~g} / 1$ albumin - that is, $0.675 \mathrm{~g} / \mathrm{kg}$ of albumin). All infusions were given at a rate of $5 \mathrm{ml} / \mathrm{kg} /$ hour in addition to maintenance fluids. Thus the $20 \%$ albumin infusion was completed in one hour, but the other two infusions only after three hours. Systolic blood pressure was measured one hour after beginning the infusion and one hour after completing the infusion, and also four hours after beginning the infusions (that is, one hour after completing fresh frozen plasma and $4.5 \%$ albumin infusion, but three hours after completing the $20 \%$ albumin infusion).

Systolic blood pressure was measured either from an indwelling arterial catheter sited for clinical purposes or using a non-invasive Doppler method. All blood pressure measurements were made with the infant in the supine position. Measurements were not made if the infants had been recently handled, were crying, or were feeding.

Arterial cannulation was attempted on all admissions to the neonatal intensive care unit if the infant's oxygen requirements were in excess of $40 \%$ for six hours or the infant had a birth weight of less than $1000 \mathrm{~g}$ and was dependent on a ventilator. The unit's routine policy was first to attempt cannulation of the umbilical artery with a 4 or 5 French gauge catheter and if this was unsuccessful a peripheral artery was cannulated with a 24 or 26 French gauge cannula. Once arterial access was gained, blood pressure monitoring was begun. The arterial line was connected to a transducer (Medex Accuflush) and thence to a continuous monitor (Horizon 2000 monitor, Mennen). This gives a continuous display of the arterial waveform and minute by minute changes in the diastolic and systolic blood pressure. The arterial waveform was considered damped if the dicrotic notch was absent ${ }^{1}$ and if there was less than a $10 \mathrm{~mm} \mathrm{Hg}$ difference between the systolic and diastolic blood pressure. Only the results of non-damped systolic blood pressure measurements were used for this study. Measurements were recorded over a 10 minute period and the mean of the results was calculated.

A Doppler technique was used for blood pressure measurement in those infants with- 
out an arterial line in situ. An appropriately sized $^{2}$ cuff (Tricomed) was placed over the infant's upper arm. A coupling gel was applied over the brachial artery and the Doppler transducer (Ultrasonic Doppler flow detector) applied to this area. The operating frequencies of the transducer were from 8 to 9.7 MHz. The cuff was slowly inflated manually using a portable Accoson sphygmomanometer and then released until arterial pulsations were audible. The systolic pressure is the first signal heard. Three measurements were made on each occasion and the systolic blood pressure was expressed as the mean of these results. No infant required a change in blood pressure measurement technique during the study.

\section{STATISTICAL ANALYSIS}

The blood pressure immediately before beginning the colloid infusion was taken as the baseline blood pressure. The change in blood pressure from the baseline one hour after beginning, one hour after completing, and four hours after beginning the infusion was expressed as a percentage of the baseline blood pressure. Differences between the three groups were assessed for statistical significance using the Wilcoxon rank sum test.

Table 1 Patient characteristics. Results given are median (range) values

\begin{tabular}{lccc}
\hline & Patient group & & \\
\cline { 2 - 4 } & $4 \cdot 5 \%$ & $\begin{array}{l}\text { Fresh frozen } \\
\text { plasma }\end{array}$ & $\begin{array}{l}20 \% \\
\text { Albumin }\end{array}$ \\
\hline Albumin & $26(23-34)$ & $26(23-34)$ \\
Gestational age (weeks) & $27(24-35)$ & $958(566-1880)$ & $860(552-1800)$ \\
Birth weight (g) & $844(690-1954)$ & $14(1-55)$ & $12(3-55)$ \\
Length of ventilation (days) & $14(6-41)$ & $2(1-3)$ & $2(1-4)$ \\
\hline
\end{tabular}

Table 2 Systolic blood pressure and colloid infusions. Results given as median (range) values in $\mathrm{mm} \mathrm{Hg}$

\begin{tabular}{llll}
\hline & Patient group & & \\
\cline { 2 - 4 } & $\begin{array}{l}4 \cdot 5 \% \\
\text { Albumin }\end{array}$ & $\begin{array}{l}\text { Fresh frozen } \\
\text { plasma }\end{array}$ & $\begin{array}{l}20 \% \\
\text { Albumin }\end{array}$ \\
\hline Baseline & $31(22-38)$ & $35(26-39)$ & $31(25-39)$ \\
One hour after beginning the infusions & $38(25-45)$ & $38(28-57)$ & $38(21-44)$ \\
One hour after completing the infusions & $39(27-46)$ & $41(29-51)$ & $37(25-55)$ \\
Four hours after beginning the infusions & $39 \dagger(19-46)$ & $41 *(29-51)$ & $34 *+(25-42)$ \\
\hline${ }^{*} \mathrm{p}<0 \cdot 05$. & & & \\
$t \mathrm{p}<0 \cdot 01$. & & &
\end{tabular}

Table 3 Change in systolic blood pressure and colloid infusions. Results given as median (range) values of percentage baseline blood pressure

\begin{tabular}{|c|c|c|c|}
\hline & \multicolumn{3}{|l|}{ Patient group } \\
\hline & $\begin{array}{l}4.5 \% \\
\text { Albumin }\end{array}$ & $\begin{array}{l}\text { Fresh frozen } \\
\text { plasma }\end{array}$ & $\begin{array}{l}20 \% \\
\text { Albumin }\end{array}$ \\
\hline \multirow{3}{*}{$\begin{array}{l}\text { Increase one hour after beginning } \\
\text { the infusions } \\
\text { Increase one hour after completing } \\
\text { the infusions } \\
\text { Increase four hours after beginning } \\
\text { the infusions }\end{array}$} & $15(-24$ to 45$)$ & $8(-10$ to 90$)$ & $7(-19$ to 46$)$ \\
\hline & $22 *(-17$ to 58$)$ & $19 *(-22$ to 77$)$ & $9^{*}(-15$ to 50$)$ \\
\hline & $22 \dagger(-17$ to 58$)$ & $19+(-22$ to 77$)$ & $5+(-18$ to 53$)$ \\
\hline
\end{tabular}

TRIAL SIZE

Using the results derived from 20 infants previously treated on our unit for hypotension with a colloid infusion we calculated that it would be necessary to randomise 60 infants (20 in each group) to detect with $80 \%$ power at the 5\% level a significant difference of $10 \%$ in the change in blood pressure between the groups.

\section{PATIENTS}

Sixty patients were recruited into the study, 20 infants in each group. Table 1 shows that there was no significant difference in the gestational age, birth weight, length of ventilation, or postnatal age between the three groups.

\section{Results}

There was no significant difference in the blood pressure of the three groups at entry to the trial or after one hour of beginning or completing the colloid infusions. At four hours after beginning the infusion-that is, three hours after completing the $20 \%$ albumin infusion, the blood pressure of that group was significantly lower than that of the $4.5 \%$ albumin and the fresh frozen plasma groups $(\mathrm{p}<0.05, \mathrm{p}<0.01$, respectively) (table 2$)$. The median increase in blood pressure one hour after beginning the colloid infusions tended to be greatest in those infants who had received $4.5 \%$ albumin. The increase in blood pressure one hour after completing the infusions was significantly greater in the infants who had received $4.5 \%$ albumin or fresh frozen plasma compared with those who had received $20 \%$ albumin $(p<0.05)$. This difference in the increase in blood pressure was even more marked $(p<0.01)$ when the three groups were compared at four hours after beginning the infusion (table 3, figure).

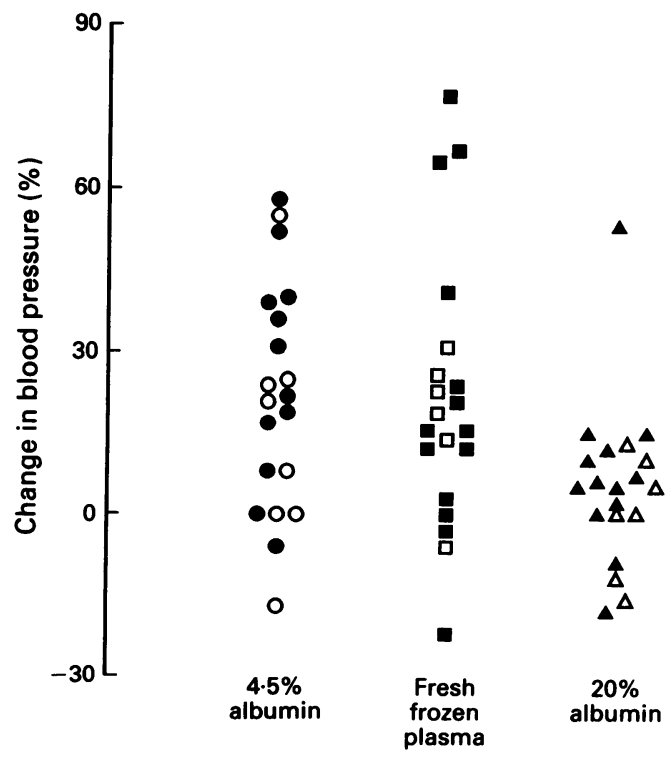

Change in blood pressure four hours after beginning the infusion. The change in blood pressure is expressed as a percentage of the baseline. Individual data shown (closed symbols indicate measurements made by the Doppler symbols indica 


\section{Discussion}

Hypotension was recorded using systolic blood pressure measurements either made directly from an indwelling arterial catheter or by using a Doppler technique. The direct arterial blood pressure results were obtained from either umbilical or peripheral arterial cannulae. We felt it reasonable to pool the results from these different sites as an earlier study $^{3}$ had shown a good correlation between blood pressure measurements obtained from peripheral and umbilical cannulae. In addition, using such an approach we had previously recorded ${ }^{4}$ arterial blood pressure results similar to those reported. ${ }^{2}$ In those infants who were without arterial lines or in whom the arterial waveform was damped, blood pressure was measured using a Doppler transducer. It has been suggested that the Doppler technique may yield inaccurate results in sick preterm infants ${ }^{5}$; this has not been our experience. ${ }^{4}$ We have previously shown that Doppler systolic blood pressure measurements have a high correlation $(r=0.96)$ with arterial results. ${ }^{4}$ The mean of the difference of paired measurements made by the Doppler technique and from an arterial catheter in 44 infants was less than or equal to $0.8 \mathrm{~mm} \mathrm{Hg}$ from days one to seven. ${ }^{4}$ Oscillometry has been a more popular noninvasive method of blood pressure monitoring than the Doppler technique. ${ }^{6}$ We chose not to use that method, however, for although it seems accurate in older infants and children ${ }^{6}$ it consistently under records the systolic and diastolic blood pressures of hypotensive very low birthweight infants. ${ }^{7}$

Although our study population were all very young, in a proportion it was not possible to make invasive arterial measurements. This was predictable from our earlier trial, which found by day four that $20 \%$ of infants no longer had an arterial catheter in situ and of those who did, a further $20 \%$ had a damped waveform. ${ }^{4}$ There was, however, no significant difference in the number of infants in each group in whom blood pressure was measured using the Doppler technique. In addition, as our study period was of only four hours duration, we did not need to change our measurement technique in any infant, thus eliminating a further source of bias.

Infants were regarded as hypotensive if their systolic blood pressure was less than $40 \mathrm{~mm}$ $\mathrm{Hg}$. This level was used as this is our routine clinical practice and has also been previously recommended. ${ }^{8}$ This level may be inappropriate for the most immature infants included in our study, but there is little normative data available for such infants on which to base a more accurate diagnosis of hypotension. As there was no significant difference in the median or range of gestational age between our three groups, our use of a single level of blood pressure on which to diagnose hypotension in unlikely to have biased our results. Other studies ${ }^{9} 10$ have used the mean rather than the systolic level, as it was felt to be more accurate than the systolic blood pressure which could be affected by damping. In this study we avoided this possible source of error by using only arterial measurements which were taken from an undamped arterial waveform. We felt it important to use systolic blood pressure levels as these can be measured in all infants regardless of the presence of an arterial line.

Albumin infusion has previously been associated with a reduction of tissue oedema, as evidenced by considerable weight loss. ${ }^{11}$ There is the theoretical concern that by increasing blood volume it might prolong the patency of the ductus arteriosus. ${ }^{12}$ In only one study has its use been associated with pulmonary oedema ${ }^{13}$ and this did not occur in three other studies. ${ }^{111314}$

Several groups have reported that albumin infusion increases blood pressure. ${ }^{13-15}$ The effects previously recorded, however, were small and transient. Compared with the present trial, a smaller amount of albumin and smaller volume of fluid was infused in all three studies. ${ }^{13-15}$

The present results suggest that the volume rather than just the total amount of protein given is more effective in producing a sustained increase in blood pressure. The larger volumes of fluid were given at the same rate and hence over a longer period of time. The prolonged infusion of protein may also have had a greater effect by producing a sustained increase in oncotic pressure. Administration by such a method may have resulted in less protein loss from the circulation, ${ }^{16}$ as the increase in albumin concentration would be expected to be smaller, ${ }^{15}$ thus resulting in a lower diffusion gradient. This hypothesis is supported by our finding of a significantly lower blood pressure in the $20 \%$ albumin group compared with the other two groups at the same time after beginning the infusion (table 2).

There was no significant difference between the three groups in the blood pressure levels or change in blood pressure one hour after beginning the infusions. At that early stage all of the infants had received the same volume of fluid related to body weight $(5 \mathrm{ml} / \mathrm{kg} /$ hour), but those receiving $20 \%$ albumin had been given a greater protein load. This further suggests that the volume of the fluid rather than protein load alone is responsible for the major effect on blood pressure.

We conclude that it is not only the amount of protein administered but also the volume of the vehicle infused that is important in producing a sustained increase in blood pressure in hypotensive preterm infants.

Ms E F Emery is supported by the British Heart Foundation. We are grateful to Ms Sue Williams for secretarial assistance.

1 Versmold HT, Kitterman JA, Phibbs RH, Gregory GA, Tooley WH. Aortic blood pressure during the first 12 hours of life in infants with birthweight 610 to 4222 grams. Pediatrics 1981;67:607-13.

2 Tan KL. Blood pressure in very low birth weight infants in the first 70 days of life. $\mathcal{F}$ Pediatr 1988;112:266-70.

the first 70 days of life. F Pediatr 1988;112:266-70.
3 Butt WW, Whyte H. Blood pressure monitoring in neonates: comparison of umbilical and peripheral artery neonates: comparison of umbilical and peripheral

4 Emery E, Greenough A. Non-invasive blood pressure monitoring in preterm infants in the first seven days of life. Eur $\mathcal{F}$ Pediatr 1992;151:136-9. 
5 Dweck HS, Reynolds DW, Cassady G. Indirect blood pressure measurement in newborns. Am $\mathcal{f}$ Dis Child $1974 ; 127: 492-4$

6 Park MK, Menard SM. Accuracy of blood pressure measurement by the Dinamap monitor in infants and surement by the Dinamap monitdren. Pediatrics 1987;79:907-14
child

7 Diprose GK, Evans DH, Archer LNJ, Levene MI. Dinamap fails to detect hypotension in very low birthDinamap fails to detect hypotension in very low birthweight babies. Arch Dis Child 1984;61:771-3.

8 Morley CJ. The respiratory distress syndrome. In:Roberton NRC, ed. Textbook of neonatology. Edinburgh: Churchill Livingstone, 1986:305.

9 Miall-Allen VM, De Vries LS, Whitelaw AGL. Mean arterial blood pressure and neonatal cerebal lesions. Arch Dis Child 1987;62: 1068-9.

10 Miall-Allen VM, Whitelaw AGL. Effect of pancuronium and pethidine on heart rate and blood pressure in ventilated infants. Arch Dis Child 1987;62:1179-30.

11 Greenough A, Greenall F, Gamsu HR. Immediate effects of albumin infusion in ill premature neonates. Arch Dis Child 1988;63:307-17.

12 Walker CHM. Plasma volume changes in the newborn. Arch Dis Child 1990;65:331-2.

13 Barr PA, Bailey PE, Sumners J, Cassady G. Relation between arterial blood pressure and blood volume and effect of infused sick preterm infants. Pediatrics $1977 ; 60$

4 Lay KS, Bancalari E, Malkus H, Baker R. Acute effects of albumin infusion on blood volume and renal function in premature infants with respiratory distress syndrome. f Pediatr 1980;97:619-23.

15 Bignall S, Bailey PC, Bass CA, Cramb R, Rivers RPA Wadsworth $\mathrm{J}$. The cardiovascular and oncotic effects of albumin infusion in premature infants. Early Hum Dev 1989;20:191-201.

16 Jobe A, Jacobs M, Ikegami M, Berry D. Lung protein leaks in ventilated lambs: effects of gestational age. $\mathcal{f}$ Appl Physiol 1985;58:1246-51. 